International Journal of English Language Teaching

Vol.10, No.1, pp., 1-12, 2022

Print ISSN: 2055-0820(Print)

Online ISSN: 2055-0839(Online)

\title{
THE INTEGRATION OF GRAMMAR TRANSLATION METHOD AND INDIVIDUALIZED INSTRUCTION METHOD IN TEACHING ENGLISH FOR GRADE 12 STUDENTS
}

\author{
Suthee Khamkaew, Ph.D. \\ School Director and English Language Lecturer \\ Wat Phrasrimahadhat Secondary Demonstration School, \\ Phranakhon Rajabhat University, Thailand
}

\begin{abstract}
This study aimed to study grade 12 students' perceptions of the integration of grammar translation method and individualized instructional method in English subjects in academic year 2020. The participants were 131 students. The questionnaire was employed and was distributed to the participants at the end of academic year 2020 during their last periods in February 2021. The results revealed that 1) The overall level of perceptions towards the classroom management was excellent (4.74), and the most three perceptions were planning and preparing the lessons (4.80), collecting and grading homework regularly (4.79), and setting clear goals and expectations for students (4.76), 2) The overall level of perceptions towards the learning activities was excellent (4.77), and the most three perceptions were getting closer to the teachers for discussion (4.87), promoting the way to share ideas with others (4.83), and encouraging to respond the questions asked (4.76), and 3) The overall level of perceptions towards the learning outcomes was excellent (4.63), and the most three perceptions were expressing and sharing ideas freely (4.78), leaning by using grammar translation method and individualized instructional method better than teacher-centered (4.73), and being able to apply learning methods with other subjects (4.69).
\end{abstract}

KEYWORDS: integration, grammar translation method, individualized instruction method, teaching English language

\section{INTRODUCTION}

Thai students have difficulty in learning English because English is not generally used and spoken in Thai context especially in schools or universities. Since Thais have learned English since they were in their primary schools, they are unsuccessful and ineffective in learning English (Kongkerd, 2013; Noom-ura, 2013). This is manifested in their low language proficiency scores according to EF English Proficiency Index 2020.Thailand is now ranked 89th among the 100 listed countries and territories in the EF English Proficiency Index 2020 which is classified as very low proficiency. This year's ranking, conducted by Switzerland-based Education First, a language school operator with branches worldwide, is based on test data from 1.3 million adults who took the EF Standard English Test (EF SET) in 2019 (www.ef.co.th). 
This low English proficiency level of Thais is generally associated with the kind of English language teaching and learning they received in their classrooms. Some studies have mentioned a number of factors why English language learning in Thai classrooms is unproductive. Firstly, teachers in Thailand are delivering the lessons in their local language focusing more on grammar (Simpson, 2011). Secondly, there is a lack of confidence and speaking opportunities for the students to practice their English language communication skills (Noom-ura, 2013). Thirdly, many teachers are not qualified to teach English, as most of them do not have a degree in English (Dhanasobhon, 2006). Lastly, English lessons are conducted in a teacher-centered classroom, making the students passive learners (Wiriyachitra, 2002). According to these mentioned problems affecting the English language learning and teaching in Thailand, the Thai government and its education institutions are working to address these issues.

Wat Phrasrimahadhat Secondary Demonstration School, Phranakhon Rajabhat University, Bangkok which is an autonomous institution directly under the central administration of Phranakhon Rajabhat University was founded in 1953 with the primary goal of being as a laboratory for student teachers and providing the educational scheme for high school levels. The school offers an educational program that promotes a high standard of learning achievement from grade 7-12. There are four majors for junior high school students which are 1) MathematicsScience, 2) Mathematics-English, 3) English-Japanese and 4) English-Chinese.

The researcher is responsible for teaching fundamental English 1-6 for grade 10-12 students emphasizing on how to promote the English proficiency in the classroom by doing various English tests or exercises. In the classroom, students will learn English grammar points or English structures or English knowledge which were clarified based on the O-NET test, GAT-PAT, TOEIC, IELTS, TOEFL, etc. The English topics could be grouped into six parts as follows; 1) Situations/ Dialogues, 2) Error identification, 3) Writing Ability (Grammar Structure) , 4) Vocabulary, 5) Reading Comprehension, and 6) Sentence Completion

Teaching English is an important issue in Thailand because learning second language is difficult for L2 learners since they cannot use English in real life situations. Therefore, teachers should always improve their strategies to promote the teaching English language (Nunn, 2011). The research applied the Grammar Translation Method and Individualized Instruction Method in teaching English for grade 10-12 students because the grammar-translation method has been considered useful for students in second language acquisition in that this method mastery of the grammatical rules and vocabulary knowledge are emphasized. Therefore, it has been hoped that in order to communicate accurately, meaningfully, and appropriately skills and practice students need are provided using the grammar translation method (Fish, 2003).

In addition, according to the different characteristics of students, their learning and achievement can be affected by diversity issues such as culture, language, learning style, and personality. Because diversity influences student behavior, educators need to consider instructional strategies 
that meet diverse characteristics of students (Johnsen, 2008). Individualized instruction method is one of the systems which consider individual differences and needs of students in teaching process, and offer instructional approaches appropriate to differences of students.

In summary, English language is a global language. Learning English improves the individual's status and opportunities in education, technology, global trades, and business. Moreover, English plays an important role like a channel of communication (Kannan, 2009). A few scholars and experts have discussed and confirmed the possibilities of the combination of the grammar translation method and the individualized instruction method. Based on the notion of student academic achievement and English teaching, this study aims to find out the students' satisfaction towards the grammar translation method and the individualized instruction method. Consequently, the results from the study can be implications for the English teachers who need to improve their students' English proficiency and for the educational institutions to design the effective teaching skills for Grade 10-12 students.

\section{LITERATURE REVIEW}

English teaching plays an important role for learners who study English as a foreign language. Many researchers have carried out various problems in all aspects of teaching process to facilitate second language teaching and learning (Larsen-Freeman, Long, and Pica, as cited in Nassaji, 2012). Wardhaugh (1969) stated that most classes are teacher-dominated, the teachers are sage on the stage and students learn everything from the teacher. Furthermore, he pointed out that students should learn their tasks and teachers can help them. To enable students to accomplish their potential learning achievement is a challenge that all education systems are confronted with. It is important to introduce new and innovative teaching methods that will provide better learning outcomes than the traditional one (Dell'Olio and Donk, 2007).

As a response to the current challenges that society imposes on education, schools focus on the dominant students' activities, on the development of his/her personality and individuality (Milijević, 2003). The teacher's role is to guide students into the world of knowledge and show them how to learn (Milijević, 2003). Since English language was a foreign language to Thai people, the continuation on the use of grammar translation method in Thai secondary schools leads to the students' weakness in skills of speaking and writing correct English sentences. This in turn accelerates the deterioration of the students' general standard in English language.

The grammar translation methods has been applied in the Thai classrooms because the purpose of the grammar translation method was to help students read and understand foreign language literature (Larsen-Freeman, 2000). It was an effective way of learning new vocabulary and grammatical structures and students would recognize the features of two languages that would make language learning easier. Danchev (1983) lists the benefits of the grammar translation method as: 1) natural and easy comparison between the target and the native language, 2) quick 
and effective comprehension control, and 3) to overcome and neutralize native language transfer. However, the use of translation in foreign language learning has been considered detrimental as it does not allow the achievement of fluency and foster communicative language use (Newson, 1998). The grammar translation method has been criticized for not giving the enough opportunity to students to get involved in the target language.

In order to boost students' learning ability, the researcher suggested that the grammar translation method should be integrated with the teaching method like the individualized instruction method because classrooms contain substantial numbers of student with diverse learning needs and abilities. Many of these students display characteristics resulting from such factors as language, intellectual and cognitive abilities, behavior, culture, or limited experiential backgrounds that can significantly interfere with successful learning (Polloway and Patton, 1997).

Individualized instruction method is the effort to organize the learning environment to take into account individual student characteristics and needs to make use of flexible instructional practices (Keefe and Jenkins, 2002), and is a system where teaching-learning activities are organized to take into account the individual interests and needs as well as the learning speed and capabilities of the students (Maisano, 2005). Individualized instruction method represents comprehensive attempts to improve learning by tailoring instruction to these individual characteristics. It is based on the assumption that students differ in aptitude, learning rate, culture, and motivation, as well as other variables (McCarthy, 1980).

In the classroom, teachers should improve the teaching and learning process when working with all types of students, both with those who are average and with those who lag behind, and those who are intellectually gifted and can adopt knowledge much faster (Bloom, at. all, 1956). In this study, the researcher's big concern of language teaching and learning is to improve the students' achievement in learning English as a second language, especially grammar and individual characteristics. Therefore, this study attempts to figure out if the grammar translation method and the individualized instruction method can help students to move forward in learning process.

\section{Objective}

To study the grade 12 students' learning perceptions of the integration of grammar translation method and individualized instructional method in English subjects.

\section{METHODOLOGY}

\section{The Participants}

This study was aimed to report on research conducted at Wat Phrasrimahadhat Secondary Demonstration School, Phranakhon Rajabhat University, Thailand. Focusing on English teaching and learning, the study was carried out to gather information in order to support the teaching and 
learning by the integration of grammar translation method and individualized instructional method in classrooms, considering its various students' learning perceptions.

The participants were 131 out of 134 students who studied English from grade 10-12. Three students were absent from the classrooms during the survey. They are grade 12 students who studies in mathematics-science major, mathematics-English major, English-Japanese major, and English-Chinese major in academic year 2020.

\section{Method of Data Collection}

To collect the data of the study, the questionnaire developing to explore the grade 12 students' learning perceptions of the integration of grammar translation method and individualized instructional method in English subjects was applied. The questionnaire was developed in terms of teaching and learning English through grammar translation method and individualized instructional methods. The questionnaire was distributed to the participants at the end of academic year of 2/2020. All participants gave the feedback by checking the items of the questionnaires during their last periods. The researchers took a week to complete the survey in February 2021.

\section{Instruments of Data Collection}

The questionnaire was particularly employed for getting the data towards students' learning perceptions of the integration of grammar translation method and individualized instructional method in English subjects. The purpose of the questionnaire of this study was to discover students' learning perceptions of the integration of grammar translation method and individualized instructional method in English subjects. The questionnaire was also developed based on the preliminary interviews with some English teachers who had experienced with grammar translation method and individualized instructional method. The questionnaire was designed in Thai, and then translated into English. The Thai questionnaire was distributed to the participants in order to minimize misunderstandings. The questionnaire was separated into three categories accounting for 14 items as follows;

1) The classroom management consisted of 4 items.

2) The learning activities consisted of 5 items, and

3) The learning outcomes consisted of 5 items.

\section{Method of Data Analysis}

The results and findings were presented in tables and figures together with full explanations. The results of the questionnaire were interpreted, categorized and tabulated on computer sheets and were calculated into the statistical values as follows:

(a) The data concerning grade 12 students' learning perceptions of the integration of grammar translation method and individualized instructional method in English subjects were presented in Mean Range and Standard Deviation. 
(b) A five-point Likert scale was used to score the levels of the satisfaction of students' opinions. It is a scale used in questionnaire to specify the level of agreement or disagreement:

\begin{tabular}{c|c|c}
\hline Scale & Perceptions & Mean Range \\
\hline 5 & Excellent & $4.50-5.00$ \\
4 & Good & $3.50-4.49$ \\
3 & Fair & $2.50-3.49$ \\
2 & Poor & $1.50-2.49$ \\
1 & Very Poor & $1.00-1.49$ \\
\hline
\end{tabular}

(c) Mean was used to interpret the average level of learning perceptions towards the satisfaction of students' opinions. The higher mean score of each activity indicates higher satisfaction. On the other hand, the lower mean score indicates less satisfaction.

\section{FINDING AND DISCUSSIONS}

English language is an international language which can improve students' status and opportunities in education, technology, global trades, and business. English also plays an important role like a channel of communication (Kannan, 2009). However, teaching English has faced with many problems in several countries because English is not their first language. L2 learners cannot develop their second language because they have no chance to use English in real life situations. Therefore, teachers should always look for useful teaching methods to reduce the difficulties of teaching English language (Nunn, 2011).

The study presented the grade 12 students' learning perceptions of the integration of grammar translation method and individualized instructional method in English subjects. This study interprets viewpoints of 131 students from Wat Phrasrimahadhat Secondary Demonstration School, Phranakhon Rajabhat University, Bangkok. The major findings and discussions of the study can be summarized as follows:

Table 1: The Classroom Management

Mean and Standard Deviation towards the Classroom Management (N=131)

\begin{tabular}{l|c|c|c}
\hline \multicolumn{1}{c|}{ Criteria } & Mean & S.D. & $\begin{array}{c}\text { Level of } \\
\text { Perceptions }\end{array}$ \\
\hline 1. Setting clear goals and expectations for students. & 4.76 & 0.48 & Excellent \\
\hline 2. Planning and preparing the lessons. & 4.80 & 0.46 & Excellent \\
\hline $\begin{array}{l}\text { 3. Motivating students to learn with various teaching } \\
\text { techniques. }\end{array}$ & 4.61 & 0.61 & Excellent \\
\hline 4. Collecting and grading homework regularly. & 4.79 & 0.46 & Excellent \\
\hline \multicolumn{1}{c|}{ Total } & $\mathbf{4 . 7 4}$ & $\mathbf{0 . 5 0}$ & Excellent \\
\hline
\end{tabular}


The results were presented in the average number as follows:

Classroom management can be managed by the teachers to observe the effects on students' learning. As Oxford (2001) stated, teaching English as a second or foreign language (ESL/EFL) is a complex task. Teachers should categorized many aspects and grouped them together such as the characteristics of the teachers, the learners, the settings, and the relevant languages (i.e., English and the native language of the learners and the teacher). All parts are related to each other and teachers cannot ignore the one part or pay more attention to another part.

According to Table 1, the results based on the questionnaire showed that the overall level of perceptions towards the classroom management was excellent (4.74). Since all grade 12 students had learned English through the grammar translation method and individualized instruction method for three years, they might feel comfortable with these teaching and learning methods. This might be because the teaching methods which the researcher provided gave wide array of opportunities to tailor and adapt instruction and learning process to the specific characteristics of individual students (Gibbons, 1970). Moreover, in the past, regular classroom teachers were ill prepared to instruction to students with different characteristics (VanTassel-Baska, 2008) and teachers thought that generally learning experiences were organized to meet needs of all groups in the classroom rather than the specific needs of individuals (Killion, 2005).

Additionally, every item surveyed was excellent. The most three perceptions which were excellent were - 1) Planning and preparing the lessons (4.80), 2) Collecting and grading homework regularly (4.79), and 3) Setting clear goals and expectations for students (4.76).

Table 2: The Learning Activities

Mean and Standard Deviation towards the Learning Activities (N=131)

\begin{tabular}{l|c|c|c}
\hline \multicolumn{1}{c|}{ Criteria } & Mean & S.D. & $\begin{array}{c}\text { Level of } \\
\text { Perceptions }\end{array}$ \\
\hline 1. Encouraging to respond the questions asked. & 4.76 & 0.51 & Excellent \\
\hline 2. Promoting the way to share ideas with others. & 4.83 & 0.40 & Excellent \\
\hline 3. Understanding the lessons more. & 4.72 & 0.50 & Excellent \\
\hline 4. Enhancing English language learning. & 4.73 & 0.47 & Excellent \\
\hline 5. Getting closer to the teachers for discussion. & 4.87 & 0.33 & Excellent \\
\hline \multicolumn{1}{c|}{ Total } & $\mathbf{4 . 7 7}$ & $\mathbf{0 . 4 5}$ & Excellent \\
\hline
\end{tabular}

The results were presented in the average number as follows:

In Thailand, people hardly speak and use English as a medium of communication because they have difficulty speaking and understanding the language. Even though Thai students have studied English since they were in their primary years at school, it has been unsuccessful and ineffective (Kongkerd, 2013; Noom-ura, 2013). To improve students' learning ability, English language teaching should be generally associated with suitable learning activities which require 
comprehending, producing, manipulating, or interacting in authentic language. Therefore, teachers are required to learn different ways to integrate language skills in the classroom and evaluate the extent to which the skills are integrated (Oxford, 2001).

According to Table 2, the results based on the questionnaire showed that the overall level of perceptions towards the learning activities was excellent (4.77). This can be explained that since the researcher applied the integration of grammar translation method and individualized instructional method in English subjects, almost of grade 12 students adapted their learning styles from passive learning to active learning because teaching English by using grammar translation method provides explicit framework to guarantee producing correct structures and expedite the learning process (Hedge, 2000). The grammar translation method helps students improve verbal agility, expand the students' vocabulary in L2, develop their style, improve their understanding of how languages work, consolidate L2 structures for active use, and monitor and improve the comprehension of L2 (Schäffner, 2002).

Also, by using individualized instruction method, teachers' role changes, since the learning activities focus on adapting teaching to the abilities, knowledge and affiliations of students. Empirical studies of the efficiency of individualized instruction method and its types (Kirby and Radford, 1976) have identified significant advantages of this type of instruction over traditional teaching, and that the issue of individualized instruction is at the core of lesson organization.

When the classroom consists of many different characteristics of students, students learning and achievement can be affected by diversity issues such as culture, language, learning style, and personality because diversity influences student behavior, educators need to consider instructional strategies that meet diverse characteristics of students (Johnsen, 2008). This diversity influences the researcher to reform the learning activities in the classroom and support students' learning. Consequently, every item surveyed was excellent related to the learning activities in the classrooms. The most three perceptions which were excellent were -1 ) Getting closer to the teachers for discussion $(4.87), 2$ ) Promoting the way to share ideas with others $(4.83)$, and 3 ) Encouraging to respond the questions asked (4.76). 


\section{Table 3: The Learning Outcomes}

Mean and Standard Deviation towards the Learning Outcomes $(\mathrm{N}=131)$

\begin{tabular}{|c|c|c|c|}
\hline Criteria & Mean & S.D. & $\begin{array}{c}\text { Level of } \\
\text { Perceptions }\end{array}$ \\
\hline 1. Promoting self-educated. & 4.63 & 0.63 & Excellent \\
\hline 2. Expressing and sharing ideas freely. & 4.78 & 0.50 & Excellent \\
\hline 3. Being proud of self-learning from difficult contents. & 4.57 & 0.70 & Excellent \\
\hline $\begin{array}{l}\text { 4. Leaning by using grammar translation method and } \\
\text { individualized instructional method better than teacher- } \\
\text { centered. }\end{array}$ & 4.73 & 0.52 & Excellent \\
\hline $\begin{array}{l}\text { 5. Being able to apply learning methods with other } \\
\text { subjects. }\end{array}$ & 4.69 & 0.56 & Excellent \\
\hline Total & 4.63 & 0.61 & Excellent \\
\hline
\end{tabular}

The results were presented in the average number as follows:

Thai is an official language in Thailand and English is adopted as a foreign language for teaching and learning in Thai schools. Many educators put a serious effort to improve English language teaching and learning in schools and making it the main foreign language in the country because understanding and speaking only Thai would be a great dilemma in the face of globalization and internationalization. Since English is as important to the domain of education, technology, global trades, and business, innovative teaching methods that are enable students to exercise their critical and analytical skills are adopted in the classrooms (Maitichon, 2011).

According to Table 3, the results based on the questionnaire showed that the overall level of perceptions towards the learning outcomes was excellent (4.63). This can be explained that individualized instruction method is the effort on the part of a subject to organize the learning environment to take into account individual student characteristics and needs to make use of flexible instructional practices (Keefe and Jenkins, 2002). Similarly, this results directly related to Dagilienè's (2012) study who conducted a survey in Kaunas to investigate the role of grammar translation method as a learning method in English language teaching. The study found out that translation is a useful tool in English language course which intensify the skills of second language students.

The most three perceptions which were excellent were - 1) Expressing and sharing ideas freely (4.78), 2) Leaning by using grammar translation method and individualized instructional method better than teacher-centered (4.73), and 3) Being able to apply learning methods with other subjects (4.69).

\section{Limitations of the Study}

This study is limited with obtained answers from questionnaires of 131 students who study grade 12 at Wat Phrasrimahadhat Secondary Demonstration School, Phranakhon Rajabhat University in 
Bangkok, Thailand in academic year 2020. As the study participants belonged to Wat Phrasirmahadhat Secondary Demonstration School, Phranakhon Rajabhat University from a single private-sector school of Bangkok, therefore the findings are only applicable to similar contexts. For generalizability, a survey based on our findings should be conducted across the province or country.

\section{CONCLUSION}

Thai students spend many years studying English in schools, but the English results based on national test are problematic. Many practitioners pointed out a few main factors contributing to the failure of English language teaching and learning: unqualified and poorly-trained teachers, poorly-motivated students, learners of mixed abilities in overly large classes, and rare opportunities for student exposure to English outside of class time (Dhanasobhon, 2006).

From this study, the researcher viewed the problems involving curricula and textbooks, assessment, and other factors supporting teaching success. The researcher carried out the English teaching and learning by using the grammar translation method and individualized instruction method in the classrooms in order to promote students' learning achievement. The results showed that the integration of grammar translation method and individualized instructional method in English subjects could be beneficial for students from lack of exposure to English and insufficient motivation of the language. Students got more opportunities to practice the language also contributes to their lack of confidence in using language. Therefore, teachers should be professional developers in creating the innovative teaching methods in order to support students with instructional/pedagogical strategies for teaching and assessing productive skills such as listening-speaking and reading-writing skills in particular.

\section{Further Study}

1) Although this study was on a small scale basis, the findings might provide a condensation of the content areas of professional development programs that need to be organized in the future. Researcher see the necessity of the integration of grammar translation method and individualized instructional method in English subjects. The other teaching methods that help improve students' English proficiency are also highly valued.

2) For any English class that is well offered, it is worthwhile to conduct a follow-up study to find out whether students satisfy with the teaching methods that the teacher tried to serve their needs or apply what they gain from the classrooms in their examination.

3) The current study presents only grade 12 students' perspectives on the integration of grammar translation method and individualized instructional method in English subjects; it may be worthwhile to take the other side of the coin i.e. students' views on English teaching and learning problems into consideration, too. 
International Journal of English Language Teaching

Vol.10, No.1, pp., 1-12, 2022

Print ISSN: 2055-0820(Print)

Online ISSN: 2055-0839(Online)

4) Since the researcher gathers the data three years after the teaching methods applied on the students, all teachers must be self-directed observers and there should be some research conducted each year in order to solve or adjust the problems might happen.

\section{References}

Bloom, B., Englehart, M., Furst, E., Hill, W., and Krathwoll, D. (1956). Taxonomy of Educational Objectives: The

Classification of Educational Goals, Handbook I: Cognitive domain. New York, Toronto: Longman, Green and Co.

Dagilienè, I., 2012. Translation as a Learning Method in English Language Teaching. ISSN 16482824 Kalbu

Studijos. 2012. 21 Nr. Studies About Languages. 2012(21): 124-129. Available from http://dx.doi.org/10.5755/j01.sal.0.21.1469.

Danchev, A. (1983). The Controversy over Translation in Foreign Language Teaching. In Translation in Foreign

Language Teaching, Paris, Round Table FIT-UNESCO.

Dell'Olio, J., and Donk, T. (2007). Models of Teaching: Connecting Student Learning with Standards. Thousand

Oaks, CA: Sage Publications.

Dhanasobhon, S. (2006). English Language Teaching Dilemma in Thailand. Retrieved January, 2013,

From http://www.curriculumandinstruction.org/index.php.

Fish, S. (2003). Is there a text in this class? - The Authority of Interpretative Communities. 12ed. Cambridge, USA: Harvard University Press.

Gibbons, M. (1970). What is individualized instruction? Interchange, 1(2), 28-52. https://doi.org/10.1007/BF02214857

Hedge, T., 2000. Teaching and Learning in the Language Classroom. Oxford: Oxford University Press.

Johnsen, S. K. (2008). Professional Standards for Reachers of Students with Gifts and Talents: The Development

Process. In S.Johnsen,J. VanTassel-Baska, and A. Robinson, Using the National Gifted Education Standards for University Teacher Preparation Programs. Thousand Oaks, CA: Corwin Press.

Kannan, R. (2009). Difficulties in Learning English as a Second Language. ESP World, 8(5), 1-4. Keefe, W. J. and Jenkins, J. M. (2002). "Personalized Instruction”. Phi Delta Kappan, 83(6).

Killion, J. (2005). Personalization. Principal Leadership (Middle School Ed), 6(3), 54-55.

Kirby, R., and Radford, J. (1976). Individual Differences. London, UK: Methuen young books.

Kongkerd, W. (2013). Teaching English in the Era of English used as a Lingua Franca in Thailand. Executive Journal, 33(4).

Larsen-Freeman, D. (2000). Techniques and Principles in Language Teaching. Oxford: Oxford University Press. 
International Journal of English Language Teaching

Vol.10, No.1, pp., 1-12, 2022

Print ISSN: 2055-0820(Print)

Online ISSN: 2055-0839(Online)

Maisano, N. M. (2005). “A work of A.R.T.: Accountability, Responsibility and Teamwork a Private School Model for Individualized Instruction”. Capella University, AAT 3159698. Martinez, G. Joseph, R. and Matichon Online Newspaper. 2011 Students failed O-NET because they lack critical thinking skills.(translated). Retrieved May 10, 2011, from: http://www.1579.moe.go.th/modules.php?name=News\&file=article\&sid=135

McCarthy, J. F. (1980). Individualized Instruction, Student Achievement, and Dropout in an Urban Elementary Instrumental Music Program. Journal of Research in Music Education, 28(1), 59- 69.

Milijević, S. (2003). Interaktivna Nastava Matematike. Banja Luka: Društvo pedagoga Republike Srpske.

Nassaji, H. (2012). The Relationship between SLA Research and Language Pedagogy: Teachers' Perspective. Language Teaching Research, 16(3), 337-365. http://dx.doi.org/10.1177/1362168812436903

Newson D. (1998). Translation and Foreign Language Learning. In K. Malmkjær (ed.), Translation and Language Teaching: Language Teaching and Translation, Manchester, St. Jerome Publishing.

Noom-ura, S. (2013). English-teaching Problems in Thailand and Thai teachers' Professional Development Needs. English Language Teaching, 6(11), 139-147.

Nunn, R. (2011). Improving Method-in-use through Classroom Observation. IRAL, 49, 55-70. http://dx.doi.org/10.1515/iral.2011.003

Oxford, R. (2001). Integrated Skills in the ESL/EFL Classroom. ESL Magazine, 6, 1-2.

Polloway, E. A. and Patton, J. R. (1997). Strategies for Teaching Learners with Special Needs. Upper Saddle, N.J.: Merrill.

Schäffner, C., 2002. The Role of Discourse Analysis for Translation and in Translator Training. Clevedon, Buffalo: Multilingual Matters.

Simpson, J. (2011). Integrating Project-based Learning in an English Language Tourism Classroom in a

Thai University. Doctoral Dissertation, Australian Catholic University, Sydney, Australia. https://doi.org/10.4226/66/5a961e4ec686b

Wardhaugh, R. (1969). Current Problems and Classroom Practices. TESOL Quarterly, 3(2), 105116. http://dx.doi.org/10.2307/3586096

Wiriyachitra, A. (2002). English-language Teaching and Learning in Thailand in This Decade. Thai TESOL Focus,

15(1), 4-9. http://citeseerx.ist.psu.edu/viewdoc/summary?doi=10.1.1.475.4155

VanTassel-Baska,J. (2008). Aligning Teacher Preparation Standards and NAGC prek-12 Gifted Program

Standards. Using the National Gifted Education Standards for Prek-12 Professional Development. Thousand Oaks, CA: Corwin Press. 